\title{
MOSEU DA
}

10

MUSEMOH

SOEHAHT

MARioptoinosts

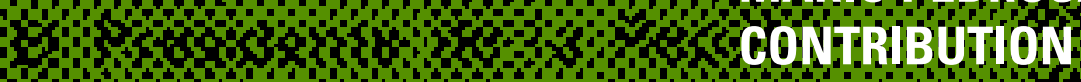

SOUDARIDDADE

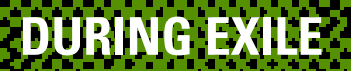

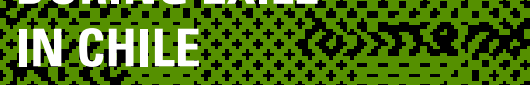

A COUTRBBUTGA:

DE MAPO PEDROSA

NO EXILIO CHILENO

MUSEODI 4

SOLDANDAOA 60MTiBuowome Mibio o boros

INE $\times 110$ GHilón 0

UUIZA MADER PALABINO

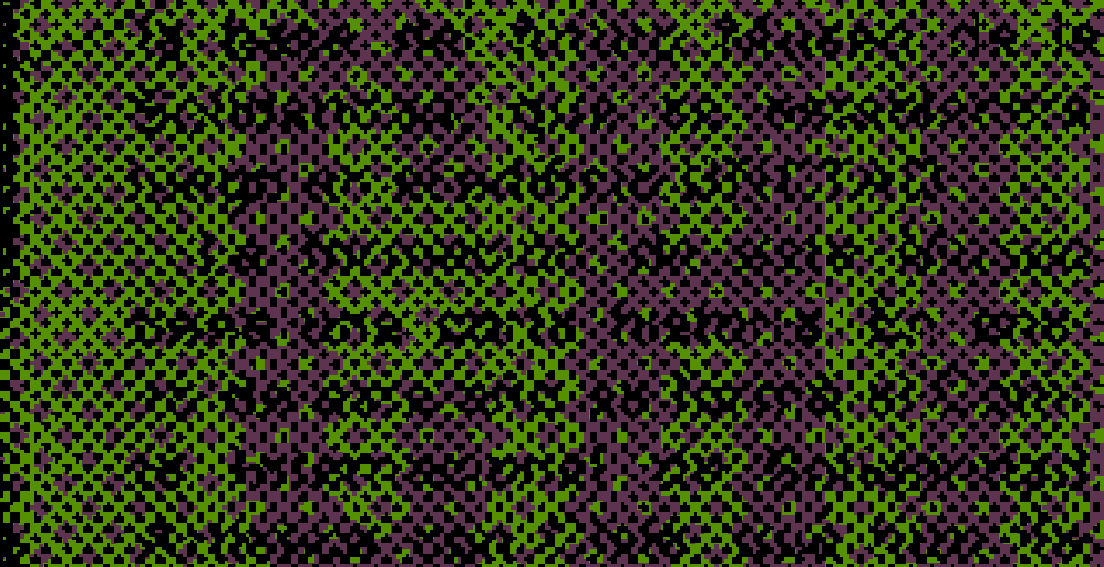


RESUMO Este artigo analisa a contribuição de Mário Pedrosa na concepção do Museu da Solidariedade, durante o governo de Salvador Allende (1970-1973). A convite do presidente, 0 crítico fundou o Comitê Internacional de Solidariedade Artística com 0 Chile para centralizar a organização da instituição, ampliar os contatos com artistas de diversas nacionalidades e garantir as doações. 0 Museu simbolizou a vocação fraterna do experimento socialista, angariando obras de artistas movidos pelo sentimento de afeto, empatia e união em prol das lutas contra o imperialismo e a dependência cultural.

PalaVRaS-ChaVe Mário Pedrosa; Museu da Solidariedade; exílio; Chile; crítica de arte

\section{ABSTRACT}

This article analyzes the contribution of Mário Pedrosa in the conception of the Museum of Solidarity during the government of Salvador Allende (1970-1973). At the invitation of the president, the critic founded the International Committee for Artistic Solidarity with Chile to centralize the organization of the institution, expand contacts with artists of different nationalities and guarantee donations. The Museum symbolized the fraternal vocation of the socialist experiment, collecting works by artists moved by the feeling of affection, empathy and unity in favor of the opposition against imperialism and cultural dependence.

KEYWORDS Mário Pedrosa; Museum of Solidarity; Exile; Chile; Art Criticism

\section{RESUMEN}

Este artículo analiza la contribución de Mário Pedrosa en la concepción del Museo de la Solidaridad, durante el gobierno de Salvador Allende (1970-1973). Por invitación del presidente, el crítico fundó el Comité Internacional de Solidaridad Artística con el Chile para centralizar la organización de la institución, ampliar el contacto con artistas de nacionalidades distintas y asegurar las donaciones. El Museo simbolizó la vocación fraterna del experimento socialista y recaudó obras de artistas movido por el sentimiento de afecto, empatía y unión en favor de las luchas contra el imperialismo y la dependencia cultural.

PALABRAS CLAVE Mário Pedrosa; Museo de la Solidaridad; exilio; Chile; crítica de arte 
por dos notivos:

gi Haseo do la solidaridad ganb este nonbre

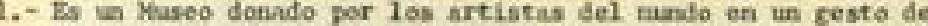
aispetia $y$ athesión al Prograus de in thidad Popular puesto en - jecucion por el Cobiemo del Preaidente Allende.

2,- Eatas obras donadas por los artistas no pueden ser fanís sefu radas poes son dentinisdas a constituir in Maseo de Arte Mode no y Experinental que sea expresión de la solidaridad hacin el pueblo de thile en este necento excepcional de su historia.

Los artistas donantes son de wuchos países de Europa y hérica, nuchos de ellos sen artistas de nenorbre une Iial $y$ aus obras valen fertunas en los grandes bercados de arte de los paises capitalintas. Ch ejetplo, estre lauchos, es el de Joan hirs, pinter que vive en Barcelonia, $y$ wia de sus pinturas pue

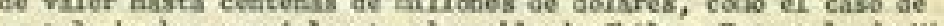
su tela hecha eapecialisente al pueblo de cirie. Esta tela do Mirs, que figura en el afiche, representa un gallo sque canta ta Alborade para el pueblo chileno.

La prinera mestra de las obras regaladas estin expuestas en el thiseo do de Calie, en quiata Norvil. La exposiefón fue inaesurada por el mesidente Allende, al 17 de Mayo del presente dio.

4o nl pueblo.

S1 Naseo de la solidaridad es un thaseo dedica-

FIGURA 1.

Museo de la Solidaridad.

Maio de 1972.

Fonte: Arquivo

Museu da Solidariedade

Salvador Allende. 
Em julho de 1970, Mário Pedrosa teve a prisão decretada pela Auditoria Militar do Exército Brasileiro, acusado de difamar a imagem do Brasil no exterior ${ }^{1}$. O crítico e um grupo de intelectuais cariocas haviam organizado um extenso parecer com provas sólidas de atentados aos direitos humanos realizados pelas autoridades brasileiras que seria enviado à Anistia Internacional e a agências de notícias estrangeiras. Pedrosa era uma figura pública de reconhecimento internacional quando, aos setenta anos, foi acusado pela polícia política. Alguns dias após ser indiciado, escreveu: "Proscrito e perseguido pelo Governo do meu país, vejo-me forçado a bater às portas de uma embaixada em busca de abrigo. Deu-me o Chile [...]. Refugiei-me por isso sob o teto da Representação diplomática de uma nação livre latino-americana" (PEDROSA, 1970, não paginado).

A chegada no Chile coincidiu com a vitória de Salvador Allende, presidente responsável pela implantação da via socialista pacífica e democrática. "Uma verdadeira constelação de intelectuais escolheu Santiago como domicílio familiar, lugar 
de trabalho e político", ampliando o contingente de estrangeiros que "ratificava a atração internacional da experiência chilena" (CÁCERES, 2019, p. 314). Após o triunfo da Unidade Popular, uma coligação de partidos de esquerda, a nação viveu uma situação ainda mais favorável de abrigo de pensadores latino-americanos, tornando-se a "capital simbólica e funcional da esquerda, realidade cristalizada com a vitória de Allende" (Ibidem, p. 315).

A condição de exílio, uma das táticas de desarticulação política promovidas pelos regimes ditatoriais, adquiriu, assim, outro significado. De acordo com a historiadora Cláudia Wasserman, a situação dolorosa da perda de raízes afetou muitos exilados, contudo, os intelectuais, especialmente aqueles que mantinham alguma trajetória na militância política, tiveram condições mais promissoras de preservar suas atividades. Em alguns casos, houve ampliação de contatos e um ambiente favorável de circulação de produções intelectuais, pois, em geral, esses pensadores e artistas eram bem recebidos por instituições de ensino e de pesquisa (WASSERMAN, 2012, p. 83).

Esse foi o caso de Pedrosa que, em seguida, foi nomeado docente no Instituto de Arte Latino-Americana (IAL) e, logo depois, recebeu o convite do presidente Allende para conceber o Museu da Solidariedade, participando diretamente dos principais 
projetos políticos do governo. Sobre a condição de exilado, o crítico escreveu: "Não é cômodo um novo exílio na velhice. Mas aqui estou e recomeço uma vida que nunca parou de recomeçar. E assim é que recomeço, inclusive, a levantar um museu de arte moderna e experimental que a vida batizou de Museu da Solidariedade" (PEDROSA, 1972i, não paginado).

Durante a Unidade Popular, o Museu da Solidariedade assumiu um lugar de protagonismo por seu caráter internacionalista e pela impressionante capacidade de mobilização global. Nessa perspectiva, podemos interpretar o gesto singular de solidariedade como uma espécie de elemento contagioso, uma ideia de comunhão coletiva transnacional que rapidamente ganhou corpo e se difundiu pelo meio artístico. Seguramente, quem mais colaborou para transmitir o sentido de solidariedade inerente à iniciativa, contando com a adesão instantânea de artistas de cada canto do globo, foi Mário Pedrosa. Embora o crítico não tenha sido o autor original da ideia, foi o grande motivador do empreendimento em nível internacional, atrelando a imagem do Museu a figuras consagradas da crítica e das artes visuais. Sobre a rápida adesão dos artistas ao projeto, Pedrosa comentou: 
A ideia nasceu em um momento de júbilo e inspiração de seus promotores. A espontaneidade da ideia era tão autêntica e respondia com tal inata justiça à sensibilidade do mundo artístico internacional que jamais foi discutida ou posta em questão. Ao chegar aos ouvidos dos artistas de Paris ou Buenos Aires, México ou Londres, Roma ou Nova Iorque e outras capitais, ela se transformou, em uma metamorfose tão natural como a do casulo em mariposa, em gesto donativo, em fruto. (PEDROSA, n.d., p. 3)

Como gestor principal, o crítico promoveu um "novo modelo de museu com uma ampla mirada ética e estética, incentivando a participação e o compromisso de uma ampla rede de colaboradores internacionais" (ZALDÍVAR, 2013, p. 13)르. A coordenação do Museu chileno foi assinalada por uma orientação internacionalista e por uma logística interna convencional, cujas demandas iniciais direcionaram-se para a ampliação do acervo, sem qualquer restrição às doações, pois em um contexto amparado pelo espírito colaborativo, $o$ ato de solidariedade não poderia ser objeto de recusa. Essa particularidade estratégica inicial de angariar um maior número de obras reportava-se à própria dimensão ideológica do Museu, a despeito de uma gestão pautada exclusivamente pela qualidade estética dos trabalhos artísticos. Portanto, é crucial compreendê-lo a partir dessa conjuntura institucional peculiar marcada por poucos recursos financeiros, 
em uma corrida contra o tempo, cujo plano piloto foi realizado mediante a união de esforços e sob um programa político definido.

A direção aos moldes mais tradicionais capitaneada por Pedrosa fundamentou-se, em um primeiro momento, nessa tática preliminar de ampliar as redes de contatos, aumentar a arrecadação de obras e vincular o Museu a figuras de prestígio. Os trabalhos enviados igualmente caracterizaram-se pela convencionalidade da linguagem e da técnica, em sua maioria pintura, gravura e escultura. O perfil tradicional do acervo se conectou à própria ideia inicial do Museu, arquitetada como uma plataforma de propaganda da experiência política chilena. Desse modo, as chances de divulgação bem-sucedida seriam maiores ao serem expostas obras mais acessíveis ao público. Porém, não havia qualquer intenção de pacificar o contato com os visitantes ou privilegiar a aquisição de obras tradicionais em detrimento de proposições mais contemporâneas, pois o conceito geral da instituição calcava-se na noção de diversidade estética e política.

Apesar da vocação plural, houve o predomínio de obras de matriz abstrata nas primeiras levas destinadas à entidade. A crítica Dore Ashton, responsável pelo envio norte-americano, chegou a denominar a instituição como o primeiro grande museu de arte abstrata do mundo (MUSEO DE LA SOLIDARIDAD, 2016). Embora 
as principais estrelas do Museu, como Joan Miró, Alexander Calder, Victor Vasarely, Joaquín Torres García ou Frank Stella, para citar alguns, fossem de períodos ou movimentos artísticos distintos, o conjunto das obras se acoplava pela linhagem abstrata.

Sabidamente, desde o final da década de 1940, Mário Pedrosa defendeu arduamente a assimilação institucional e a crítica da arte abstrata, levando-a para o centro do debate público. O autor o fez por acreditar no poder de alcance de uma linguagem universal (ou internacional), de plasticidade inovadora, que poderia atualizar um país periférico como o Brasil. No entanto, a batalha de Pedrosa pela atualização da arte, segundo Sônia Salzstein, não foi mera "plataforma da internacionalização pela internacionalização, ou de absorção das linguagens abstratas como panaceia para os problemas do descompasso cultural". Salzstein aponta, ainda, que a singularidade de Pedrosa se deu justamente pela opção por um "espírito mais ventilado e internacionalista", sem jamais deixar "de valorizar uma densidade local" (SALZSTEIN, 2001, p. 80).

No período que antecedeu o exílio no Chile, a reflexão de Pedrosa foi gradualmente alargada, e seu arsenal crítico passou a incluir a esfera participativa como forma de criação coletiva, a despeito da unicidade do objeto artístico. A participação ampliada, equivalente ao "exercício experimental da liberdade", 
estabeleceu-se como contraponto à obra de arte como mercadoria, renovando o anseio utópico das vanguardas históricas de outrora. Foi justamente nessa chave reflexiva que Pedrosa interessou-se pelos jovens artistas da época, como Hélio Oiticica, Lygia Clark e Antonio Dias. Os dois últimos doaram obras para o povo chileno, e o primeiro, cujas propostas foram lidas por Pedrosa na direção da "arte pós-moderna", tornou-se paradigmático para as etapas futuras do Museu da Solidariedade, que acabaram nunca se concretizando por conta do golpe militar, em 1973.

A experiência revolucionária no Chile, a convivência com os principais atores políticos e a aproximação com a agenda latino-americanista das instituições provocaram uma guinada na concepção crítica de Mário Pedrosa. A filósofa Otília Arantes nomeou de "O Ponto de Vista Latino-Americano" o corpus crítico produzido após a vivência chilena (ARANTES in PEDROSA, 1995, p. 313). Nesses textos é possível observar a recuperação de tradições que não haviam sido capturadas pela historiografia canônica, como as práticas e os saberes oriundos das culturas popular e indígena. Além disso, havia em seu discurso uma nova convicção geopolítica, caracterizada pela mobilização de um vocabulário crítico aliado às pautas terceiro-mundistas, as quais compreendiam a emergência de um reordenamento geográfico e a inclusão de povos oprimidos. A 
contrapelo do conhecimento ocidental, encarado como decadente, Pedrosa propunha uma mudança de latitude ancorada no Terceiro Mundo, território de onde viria "a tarefa criativa da humanidade" (PEDROSA, 1995, p. 336).

Em seu percurso crítico, o autor sedimentou uma metodologia original a partir do acordo entre as tendências internacionais e a realidade local (ARANTES, 2001, p. 45). Essa relação dialética garantiu a adoção de um modelo de modernidade ampliada, que acolheu produções tão plurais quanto a arte dita primitiva, a arte dos pacientes psiquiátricos, a arte realizada por crianças e demais criações concebidas fora do crivo oficial. Ao longo de mais de quarenta anos de atividade crítica, o pensamento de Pedrosa não se manteve constante e homogêneo. Ao contrário, nota-se que as tendências artísticas que defendeu chegaram a ocupar polos opostos, conforme pontuara Ferreira Gullar:

em alguns momentos, ele defende, com igual entusiasmo, expressões artísticas aparentemente contraditórias. Mas essas contradições, se por um lado refletem o seu caráter de homem permanentemente engajado, por outro indicam a complexidade de seu pensamento estético, a profundidade de sua indagação. (GULLAR, 1981, não paginado) 
No Chile, o comprometimento e o alcance público das reflexões dePedrosa foramatualizados, assim como a predisposição dialética presente em sua trajetória, que passou a incluir um viés latino-americanista, sobretudo na produção escrita. A gestão do Museu da Solidariedade representou essa singularidade crítica, ao evidenciar a continuidade desses dois percursos: um internacionalista, baseado na escolha do órgão curatorial e na formação do acervo, com predominância da arte abstrata, e o outro, de retórica latino-americanista, visível especialmente no aparato discursivo e conceitual da entidade.

É crucial situar Pedrosa nessa discussão, pois o radar reflexivo do autor manteve-se permanentemente atento aos acontecimentos políticos e às mudanças sociais, que acompanhou com responsabilidade intelectual. A sensibilidade terceiromundista, catalisada pela experiência noChile, foi objeto deanálise do crítico desde a década de 1950, quando os países do chamado Terceiro Mundo despontaram como novas forças políticas, alterando a lógica bipolar do pós-guerra. O historiador Dainis Karepovs apontou que Mário Pedrosa observou com entusiasmo o processo de aprofundamento do que mais tarde se intitularia de terceiro-mundismo, em reflexões realizadas em artigos sobre a Conferência de Bandung, de 1955 (KAREPOVS, 2017, p. 139). 
Essa Conferência, que reuniu países asiáticos e africanos, foi relevante em termos geopolíticos ao estruturar uma dinâmica política inédita e promover a cooperação econômica e cultural entre os países não alinhados. Muitas nações participantes eram recém-independentes, então havia um projeto de fortalecer redes autônomas, sem a interferência das duas superpotências. A análise de Pedrosa sobre o evento ratificava a importância do estabelecimento de um eixo político independente de Washington e Moscou, conclamando que finalmente as vozes da Ásia e da África seriam ouvidas, e terminava aproximando a pauta emergencial dos países não alinhados à realidade latino-americana:

O êxito da Conferência Afro-Asiática nos toca de muito perto. Nós, da periferia política do mundo estimamos que a iniciativa asiática proceda. Os povos latino-americanos, em sua imensa maioria, pertencem também à família dos bilhões de deserdados da terra. Na luta pela melhoria do nível de viver de nossos povos, obstáculos internacionais, economicamente removíveis, no entanto. Eis porque nossa maneira de ver os negócios do mundo não difere muito da dos povos da Birmânia, Indonésia ou Índia. (PEDROSA, 1955, não paginado)

Os movimentos de liberação nacional, frutos dos processos de descolonização nas décadas de 1950 e 1960, emergiram como 
uma nova possibilidade de distribuição política, impondo fim aos antigos impérios coloniais. Esse conjunto de nações passou a ser denominado Terceiro Mundo $\mathrm{o}_{-}^{3}$ e a pauta reivindicatória tinha por foco a superação do subdesenvolvimento econômico, resultante da condição periférica e da exploração colonialista eimperialista. Sem dúvidas os movimentos de descolonização africana, a Revolução Cubana e a resistência vietnamita foram marcos essenciais para o fortalecimento das ideologias terceiro-mundistas (GILMAN, 2003, p. 45).

Esses princípios se aproximavam da via socialista chilena proposta por Allende, que defendeu uma política autônoma de não alinhamento e a imposição da soberania das nações periféricas frente ao imperialismo norte-americano (FERRERO, 2008, p. 217). A teórica argentina Claudia Gilman apontou que as expectativas sobre o poder de alcance revolucionário do Terceiro Mundo se renovaram, alterando a perspectiva eurocêntrica ou ocidentalista por um viés policêntrico. Essa transformação geopolítica e epistemológica "foi uma estrutura de sentimentos que atravessou o mundo" (GLIMAN, op. cit., p. 41).

Certamente, os ecos dessa "estrutura de sentimentos" impactaram o programa político e cultural da Unidade Popular. Por esse ângulo, o Museu da Solidariedade nasceu como um projeto 
“anti-imperialista para os povos do Terceiro Mundo" (BERRÍOS, 2017, p. 87), tendo seu acervo erguido a partir de obras doadas por artistas movidos pelo sentimento de afeto e empatia ao processo socialista chileno. O empenho coletivo dessas contribuições globais transcendia o mandato de Allende, cruzando fronteiras e congregando lutas similares contra o imperialismo norteamericano e a dependência econômica e cultural.

\section{OPERACIÓN VERDAD:}

PRIMÓRDIOS DO MUSEU

A ideia inicial do Museu surgiu de um encontro de intelectuais reunidos para formular estratégias de comunicação que freassem a circulação de propagandas e informações conspiratórias contra o governo popular, as quais contavam com o envolvimento direto dos Estados Unidos. Desde a ascensão de Allende, o governo norte-americano vinha criando diferentes táticas para desestabilizar o programa socialista. Uma delas foi amparar financeiramente o jornal mais popular e de maior tiragem no país, o El Mercúrio. Tradicionalmente conservador, 
o periódico apoiou uma intensa campanha contra Allende, com “incontáveis artigos e editoriais virulentos e incendiários, nos quais induzia a oposição a lutar contra o governo da Unidade Popular" (KORNBLUH, 2004, p. 84).

Nesse quadro de recrudescimento midiático foi criada a Operación Verdad, uma estratégia de contrainformação, ocorrida em abril de 1971, que convidou intelectuais, políticos, músicos, artistas e críticos estrangeiros para conhecerem as transformações em curso no governo Allende, dentre eles, o crítico de arte José María Moreno Galván e o pintor Carlo Levi. Em um contexto favorável a trocas artísticas e políticas, Galván e Levi tiveram a ideia de criar um museu com obras doadas por artistas internacionais solidários à causa chilena. Assim surgiu o Museu da Solidariedade ${ }^{4}$ que, inicialmente, foi chamado de Museu de Arte Moderna e Experimental. Em resposta à oposição conservadora e à frente midiática conspiratória, alvoreceu um Museu amparado pelo ideal de união e solidariedade, envolvendo uma rede global de apoiadores.

Durante a Operación Verdad, Mário Pedrosa encontravase na Índia como jurado da Trienal de Nova Deli. Ao voltar a Santiago, reuniu-se com Miguel Rojas Mix, diretor do IAL, José Balmes, pintor catalão, e o cineasta uruguaio e editor da Revista 
Marcha Danilo Trelles a convite do diretor do Departamento Cultural da Presidência da República. Nesse encontro, a sugestão inicial de Moreno Galván e Levi foi retomada e a ideia de criar um Museu foi concretizada. Para concentrar a organização da nova iniciativa, foi estruturado um Comitê Internacional presidido por Pedrosa (n.d, p. 1).

O crítico começou a esboçar o Comitê Internacional de Solidariedade Artística com o Chile (CISAC), congregando críticos, intelectuais e artistas. Um dos pressupostos iniciais para participar do Comitê era o perfil político progressista e o comprometimento com a causa socialista chilena ${ }^{5}$. Mário Pedrosa era a figura mais habilitada para articular essa rede de contatos, devido à longa trajetória ligada à Associação Internacional de Críticos de Arte (AICA), além da presença em júris de diversas Bienais e como diretor da VI Bienal Internacional de São Paulo, em 1961.

No final de 1971, o Comitê Internacional estava formado. Seus integrantes eram Jean Leymarie, diretor do Museu de Arte Moderna de Paris; Edward de Wilde ${ }^{6}$, diretor do Museu Stedelijk de Amsterdã; Louis Aragon, poeta ligado ao surrealismo; Giulio Carlo Argan, historiador da arte italiano e membro da AICA; Rafael Alberti, poeta espanhol; Juliusz Starzybsky, membro da 
AICA; e Dore Ashton, crítica de arte e ativista norte-americana. A presença latino-americana foi composta por Aldo Pellegrini e Mariano Rodríguez, que já possuíam vínculo com o Instituto de Arte Latino-Americana ${ }^{7}$. Junto a eles, também estavam os idealizadores iniciais do Museu, Carlo Levi e José María Moreno Galván.

O gesto comunitário de apoio e empatia ao processo chileno se consolidou ao redor de dez nações - Itália, Holanda, França, Estados Unidos, Espanha, Polônia, Uruguai, Argentina, Cuba e Brasil -, comprovando o prestígio e a importância da entidade. Posteriormente, outros países, como Inglaterra e Suíça, aderiram ao Comitê, ampliando mais ainda os radares artísticos do Museu no Chile. Cabe destacar a centralidade de Pedrosa para o êxito do Comitê, por meio de seu reconhecimento internacional, além da ética e do compromisso público. Durante a gestão do CISAC, o crítico trocou inúmeras correspondências e realizou uma série de viagens aos Estados Unidos è̀ Europa com a finalidade de divulgar o projeto chileno e angariar obras. Também foi mérito de Pedrosa a celeridade da iniciativa, que, em menos de quatro meses, colheu os primeiros frutos. A vocação solidária foi tão imediata que nenhum artista doador se preocupou em enviar um certificado de doação de obra ao Museu (ZALDÍVAR, 1991, p. 24). 
No período de formação do CISAC, Salvador Allende escreveu a Moreno Galván, agradecendo-lhe os esforços em prol do "Museu de Arte Moderna" que o espanhol havia imaginado na ocasião da Operación Verdad. Um dos planos do presidente era coincidir a inauguração do Museu com a data de abertura da Terceira Conferência das Nações Unidas do Comércio e Desenvolvimento (UNCTAD III), marcada para abril e maio de 1972, como demonstra esse trecho:

Seria muito significativo se pudéssemos inaugurar seu projetado Museu
de Arte Moderna no mesmo momento dessa Conferência. Constituiria
uma demonstração de solidariedade dos artistas progressistas de todo o
mundo ao nosso processo político [...]. Abusando de sua vontade, desejo
lhe pedir muito encarecidamente que acelere os esforços para tornar
efetiva essa iniciativa tão significativa para o Chile. (ALLENDE, 1971,
não paginado)

A carta a Galván reforçava o lugar prioritário da arte e da cultura no programa político de Allende. Desde o período inicial de idealização do Museu, a entidade era encarada como um motor fundamental do processo revolucionário. 


\section{MIEM 3ROS DEL GOMH EN ECUTIVD}

\section{LQUIS ARAGON}

JEAN LEYMARIE

GIULIO CARLO ARCAN

E. OE WILOE

DCRE ASHTON

BAFAEL ALBERT

JENADOR CARLO LEVI

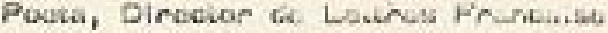

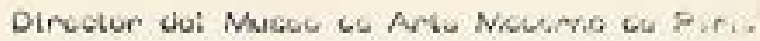

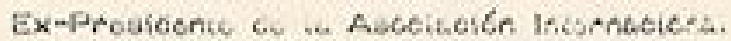
de Crítsos de ario.

Director del Mutico bu Ambterchim

Critice on Arte rorscamericuno

\section{Peena espentiol}

Pintor y ascertor tailioric
FIGURA 2.

Membros do CISAC - Comitê Internacional de Solidariedade Artística com o Chile. Fonte: Arquivo Museu da Solidariedade Salvador Allende.

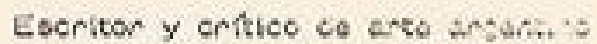

Profesor y eritice des aria pecheo

Pintor, Sub-Director de ia Cash Zs Las Amácicas

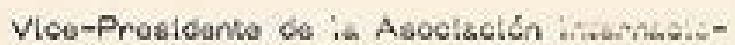
nat de criticos de Arto.

Cinefsta. Consuitance det Dapro. de -nine Artes de U.N.E.S.C.O.

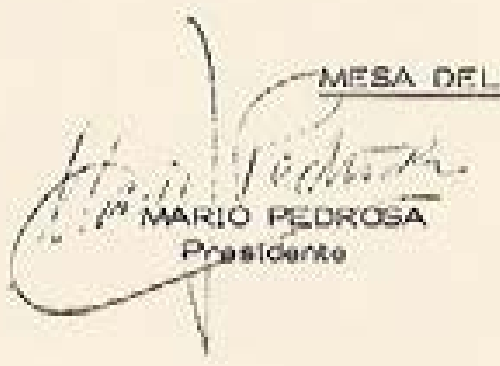$$
\text { DANILO TKZ }
$$$$
\text { Socrotertis }
$$

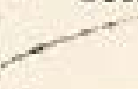


Danilo Trelles e Mário Pedrosa, em nome dos membros do CISAC, lançaram as diretrizes principais do Museu, divididas em cinco pontos sob o título "Declaração Necessária”- O primeiro ponto ressaltava que a formação do CISAC fundava-se no gesto coletivo dos artistas de renome internacional, em simpatia com as reformas revolucionárias no Chile. Eles se uniam por uma sociedade mais justa, livre e humana. O segundo apontava a importância dos artistas nos processos revolucionários ao longo do século $\mathrm{XX}$, já que o socialismo não deveria ser uma bandeira restrita às classes operárias, mas englobar artistas e intelectuais engajados contra a incorporação de suas produções pelo mercado capitalista. O terceiro ponto, central para todo o escopo conceitual do Museu, discorria sobre a função social do artista na América Latina. A produção e a circulação de obras de arte deveriam ser ampliadas em prol da coletividade, em oposição ao elitismo segregador das coleções privadas. Além disso, as obras de arte não poderiam se restringir apenas aos grandes centros metropolitanos, devendo alcançar as "grandes áreas desprivilegiadas no Terceiro Mundo" (PEDROSA; TRELLES, 1972, p. 8). Nesse contexto, o Chile representava todo o mundo subdesenvolvido e oferecia as "melhores condições para tornar-se um centro cultural autêntico a serviço de seu povo e dos povos irmãos da América Latina” (Ibidem, p. 8). O quarto ponto 
indicava o potencial mobilizador da "via chilena do socialismo", que angariava trabalhadores da cultura de vários países, movidos pelo sentido humanista e libertário da política. Por fim, o quinto ratificava os "mais profundos sentimentos de gratidão e respeito" do CISAC aos artistas que se solidarizaram com o Chile (PEDROSA; TRELLES, 1972, p. 8).

Decerto o terceiro ponto da "Declaração Necessária" é o mais relevante para entender a centralidade do projeto político capitaneado pelo Museu da Solidariedade, em sintonia com a dimensão social da arte reivindicada por Pedrosa. Em ambos os casos, há a defesa incondicional da emancipação do objeto artístico do sistema de arte convencional, cuja trajetória foi constantemente determinada pela lógica do mercado e por seus mecanismos de atribuição de valores. Ao definir a doação como critério exclusivo da coleção de um acervo público ligado a uma entidade fora do eixo hegemônico, o discurso do Museu reiterava a inversão desse sistema tradicional de produção, distribuição e circulação de obras de arte. Segundo Pedrosa, a instituição chilena representava a "vitória sobre a pobreza, a rotina, o mercantilismo e um pequeno passo em direção a um novo condicionamento social para a arte em sua relação com os trabalhadores, as minorias condenadas" (PEDROSA, 1973C, não paginado). 
Pedrosa costumava comparar o "pequeno país” chileno à coragem de um "David" que enfrentava "a sombra gigante de um Golias imperialista" . Uma das formas de atenuar a submissão ao imperialismo era fortalecendo uma política cultural própria que não se baseasse exclusivamente na importação de valores culturais estrangeiros, sobretudo aqueles que bloqueassem o desenvolvimento "tanto no plano material como no espiritual" (PEDROSA, 1995, p. 318). Em suma, o Chile e outras regiões do Terceiro Mundo deveriam unir-se para se libertar da dependência dos países metropolitanos. Nessa perspectiva, não é mero acaso que Pedrosa tenha passado a utilizar com frequência em seu corpus escrito o termo "Terceiro Mundo" para assinalar a importância da mudança de latitude cultural e política nessa região. Em certa ocasião, o sociólogo Florestan Fernandes apontara que após itinerário chileno, Pedrosa "trouxe uma visão mais rica dos problemas mundiais e da situação dos países do $3^{\circ}$ Mundo" (FOLHA DE S. PAULO, 1981, não paginado).

Em compasso com o perfil de pluralidade ideológica do governo Allende, o Museu encarnou esse caráter plural e aberto para receber obras de todas as tendências e estilos: "nenhum ismo deve ser excluído", escrevera Pedrosa a Ashton (PEDROSA, 1972b, não paginado). O propósito basilar da primeira etapa da 
instituição amparou-se na aquisição de obras mais "convencionais em nosso sentido (arte moderna)", de acordo com o crítico. Buscava-se, igualmente, organizar uma seleção de obras de artistas consagrados, a fim de atrair a confiança do governo e da opinião pública no “êxito do empreendimento" (PEDROSA, 1972g, não paginado). A Hélio Oiticica, o autor compartilhou como seriam elaborados os processos museológicos e as estratégias prioritárias referentes às etapas iniciais da entidade, todavia, em correspondência, evidenciou o plano de o Museu ganhar um lugar próprio até o final de 1972 e a ideia de que nessa futura sede houvesse um espaço reservado à “arte pós-moderna”.

Estamos procurando reservar, na localização dos espaços, para o museu, áreas para a arte pós-moderna (vide MP) a fim de abrigar as experiências de H.O e sequazes na categoria das "atividades creatividades" (Vide MP) etc, etc. É nossa ideia fazer, então ou depois, uma verdadeira assembleia de novos artistas, "não artistas", ou "anti-artistas" (?), em que se discutam problemas de estéticas-sociais contemporâneas, etc, etc. (Ibidem, não paginado)

Pouco antes do exílio, Mário Pedrosa refletiu sobre o esgotamento da autonomia estética, situando o comprometimento da arte integrada à vida social como uma atividade legítima. A propósito 
desse "fenômeno cultural e mesmo sociológico inteiramente novo", escreveu: "já não estamos dentro dos parâmetros do que se chamou de arte moderna. Chamai a isso de arte pós-moderna, para significar a diferença. Nesse momento de crise e de opção, devemos optar pelos artistas" (PEDROSA, 2007, p. 92).

Seguindo essa linha, o autor tinha noção da importância do incentivo a um espaço experimental destinado a essas proposições artísticas ampliadas, em sintonia com a ideia de museu como uma "luva elástica para o criador livre enfiar a mão" (Idem, 2004, p. 341). Seguramente, Mário Pedrosa advogava por uma concepção arejada de museu, cujo programa abarcou um entendimento ampliado de arte, como o estímulo a propostas mais experimentais, caso contrário, àquela altura, não receberia cartas de artistas de tradições estilísticas tão distintas. As correspondências com esses artistas, sobretudo as trocas com Hélio Oiticica, revelavam a maneira como o pensamento museal do crítico amparou-sena compreensão de museu como laboratório de experiências culturais, admitindo a prática de múltiplas vivências que estimulavam o ato criador. Não obstante, o cenário de acirramento político no Chile contribuiu para que a primeira opção museológica do crítico fosse pragmática e, portanto, calcada na arrecadação de obras-primas cujos espaços de resguardo se adequavam mais à noção tradicional de museu - que classifica 
e armazena - do que à de laboratório. Pedrosa dizia que a vocação convencional dessa primeira etapa era limitada, porém, intencional, "quando se trata acima de tudo de organizar uma coleção de obras para o nosso museu" (PEDROSA, 1972g, não paginado).

Desde o final da década anterior, instaurou-se um clima de revolta e mobilização política desencadeado pela Guerra do Vietnã, pelo maio francês e pelos movimentos de descolonização que fortaleciam a ideia de colapso do sistema capitalista. Nesse panorama, ganhou destaque o papel de artistas e intelectuais envolvidos em protestos, como o boicote à Bienal Internacional de São Paulo, em 1969, e projetos de doação e arrecadação de fundos para causas políticas. Contudo, havia dentro do CISAC um sentimento de receio de que o caráter apolítico de alguns artistas, sobretudo os norte-americanos, dificultasse a contribuição de obras ${ }^{10}$. Somava-se a esse entendimento o fato de que muitos artistas, de acordo com Dore Ashton, não possuíam quaisquer informações sobre a revolução socialista de Allende, portanto, não os entusiasmava fazer uma doação gratuita a um museu chileno (ASHTON, 2013, p. 38). A crítica norte-americana havia se envolvido em diferentes frentes políticas desde a década anterior, a exemplo da organização de protestos, como o Angry Arts Week, que, durante uma semana, reuniu mais de seiscentos artistas contra a guerra do Vietnã, em 1967. 
A tomada de consciência da classe artística deveria levar em conta o fator político e social da realidade chilena, bem como a generosidade que rompia com o funcionamento convencional do sistema de arte que, de forma reiterada, favoreceu a produção dos grandes centros metropolitanos. Para Pedrosa, a política ia além de uma decisão exclusivamente partidária, relacionando-se sem intermediários com a dimensão ética da arte e da vida, conforme escrevera a Ashton:

Eu acho que as pessoas como nós não podem escapar de tomar partido. Isso é política? Claro que é, mas é principalmente uma opção, uma opção ética, um sentimento de participação em um projeto maior que o negócio usual de cada um. E eu penso e espero que os artistas, apesar de sua natureza egocêntrica, sejam mais sensíveis a isso. (PEDROSA, 1973c, não paginado)

A crítica foi a integrante mais ativa do CISAC, confirmando a característica de multiplicidade ideológica do Museu. A representação significativa dos Estados Unidos simbolizou uma aproximação artística entre os países que se enfrentavam na arena política (MACCHIAVELLO, 2013, p. 41). Desde o começo, Ashton se mostrou engajada no projeto, prometendo dar o seu "melhor para obter o máximo de qualidade possível" nas doações (ASHTON, 1972, 
não paginado). Em 1971, propôs a realização de uma festa em Nova York aos artistas "amigos da Revolução Chilena" para conseguir doações e apoio (Idem, 1971, não paginado).

Ao longo do ano de 1972, diversos artistas entraram em contato com o crítico, demonstrando a amplitude das redes e o gesto de fraternidade à experiência socialista. Um deles foi Antonio Dias, que, de passagem por Nova York, escreveu a Pedrosa. Alguns anos antes, o autor havia publicado um artigo sobre o artista paraibano, situando-o na geração de "popistas do subdesenvolvimento", cuja "necessidade desalienante" o afastava da tradição pop norteamericana, a quem destinava um olhar reticente, ao enxergar no movimento metropolitano uma "satisfação publicitária do consumismo pelo consumismo" (PEDROSA, 2004, pp. 368-370). O artista brasileiro vivia em Milão há alguns anos e se prontificou a acionar artistas italianos, de modo que se pudesse "conseguir uma seleção do melhor que se faz hoje na Itália”. Sobre o seu processo artístico, Dias compartilhou que havia se afastadotemporariamente da pintura, para experimentar "outros tipos de trabalho" com filmes e proposições que lhe permitissem iniciar uma outra relação "com o trabalho de pintura" (DIAS, 1972, não paginado). A partir dessas novas experiências, propôs uma obra específica ao Museu: "pensei em uma enorme bandeira vermelha, só vermelha, sem nenhum 
desenho ou inscrição [...] a ser alçada fora do museu (no jardim?)", e seguia:

Eu gostaria muito que a bandeira fosse confeccionada aí no Chile e que fosse muito forte como medida, como cor e como altura. Gostaria que fosse uma coisa muito clara, visível para todo o povo [...]. Bacana mesmo seria fazer uma foto da bandeira já montada no exterior do museu e imprimir uma cartolina postal que seria distribuída a todo o visitante do museu. Esse trabalho eu acho que seria muito importante para mim vê-lo realizado aí. É um trabalho que representa um monte de coisas ao mesmo tempo. (DIAS, 1972, não paginado)

- ser peniourato no mlerno to nuscu, uarca obra te Arte". Pensei una enorme banteina verwella, to ver. netha, sem nexhum resencho on incricio, com as meinTas "claimicas" he une giqautsca henbsing ( $5 \times 8$ mits, talver) a ser alcada fork to musen (no farim?

\section{FIGURA 3.}

Detalhe do projeto de bandeira de Antonio Dias.

Carta de Antonio Dias a Mário Pedrosa.

17 de março de 1972.

Fonte: Arquivo

Museu da Solidariedade

Salvador Allende
BASE EM CIMENTO COM

MASTRO COM CORDis, - MAIS ACTO POSSIVE

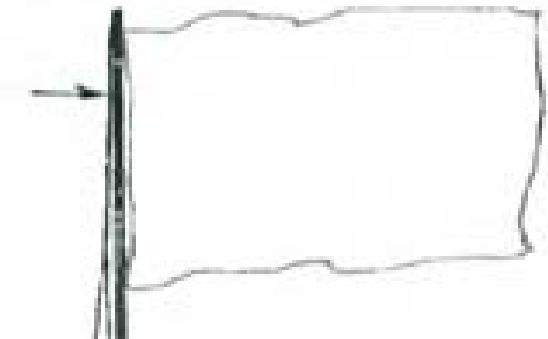

1MS CRICAO

R8 UTE BARA BANDETRA Se DVO

ANTONTO DTAS ganaetra recmelta FEITA EN LA (OU NO TECIDO QOE FOR REGULAMENTAR P. BANDETEASI 
Evidentemente, uma bandeira vermelha carregava emsias disputaspolíticasdaqueleperíodo, marcadopelaGuerraFria epela polarização política entre os Estados Unidos e a União Soviética. Contudo, por adversidades, a bandeira não foi confeccionada, embora Pedrosa tivesse aprovado o projeto ${ }^{11}$. Em resposta a Dias, ele fez algumas considerações à proposta, sugerindo ao artista que acrescentasse ao título "Projeto para bandeira do povo do terceiro mundo, que é, realmente, o nosso povo e simboliza as aspirações revolucionárias das massas subdesenvolvidas da Ásia, África e Am. Latina” (PEDROSA, 1972d, não paginado). Essa perspectiva radical de Pedrosa foi claramente impactada pela vivência chilena, e seus ecos se concretizaram nos escritos produzidos nesse período. A revolução em marcha simbolizava a luta contra a submissão, e, nesse entendimento, o Museu gerido pelo crítico tornou-se um modelo "cultural autêntico a serviço de seu povo e dos povos irmãos da América Latina" (PEDROSA; TRELLES, 1972, p. 8).

No começo de abril de 1972, quase trezentas obras haviam chegado ao Chile. Mário Pedrosa se engajou para concretizar o envio brasileiro; entretanto, estava ciente das limitações que os artistas teriam ao despachar os trabalhos na embaixada, em Brasília. Em uma carta a Niomar Moniz Sodré, ele alertou 
à presidenta de honra do Museu de Arte Moderna (MAM), no Rio de Janeiro, e sócia do jornal Correio da Manhã sobre tais dificuldades: "é claro que não se pode esperar, hoje, grande número de doações por parte de artistas do Brasil. Um pequeno número seria mais que representativo e satisfatório" (PEDROSA, 1972c, não paginado). Para somar os esforços, o crítico também escreveu a Aracy Amaral, pedindo seu auxílio para formalizar a participação dos artistas brasileiros. Com a crítica e historiadora da arte, partilhou sua análise a respeito da discrepância da presença carioca em relação à paulistana, propondo alguns nomes considerados indispensáveis, como os de Alfredo Volpi, Lasar Segall, Lívio Abramo e outros mais contemporâneos, como Mira Schendel, Amélia Toledo e Claudio Tozzi, aproveitando, ainda, a oportunidade para contar que o Museu havia recebido obras de Joan Miró, Max Ernst, Mauro Marini e Victor Vasarely (PEDROSA, 1972e, não paginado).

A carga com as obras já estava a caminho quando foi barrada por um general brasileiro no aerporto do Rio de Janeiro. Sobre o episódio, Pedrosa descreveu: "do Brasil vinha um bom grupo, mas na última hora um general meteu a pata e parou tudo à porta do avião (aquela gente até morde, passando-se perto)" (FIGUEIREDO, 1982, pp. 19-20). Os artistas brasileiros 
residentes fora do país conseguiram efetivar as doações. De Paris, Lygia Clark, Sergio Camargo, Flávio Shiró, Arthur Luiz Piza, Sérvulo Esmeraldo e Frans Krajcberg enviaram obras à entidade (FIGUEIREDO, 1982, pp. 19-20).

INAUGURAÇÃO DO MUSEU:

O CANTO DA NOVA ALVORADA

A inauguração do Museu da Solidariedade ocorreu no dia 17 de maio de 1972, nos espaços do Museu de Arte Contemporânea da Universidade do Chile (MAC). A mostra ficou aberta até o dia 2 de julho e apresentou ao público cerca de 279 obras. A primeira exposição da entidade foi também um ato simbólico de projeção do Museu, cujo planejamento amparava-se na continuidade de arrecadação das doações. Portanto, "essa inauguração não era a definitiva, mas um esboço do que seria este grande Museu de arte moderna e experimental" (ZALDÍVAR, 1991, p. 27), cujo plano ancorava-se na continuidade da divulgação da entidade aos artistas estrangeiros para ampliar o acervo.

A abertura foi palco do discurso do presidente Salvador Allende, que proferiu os agradecimentos diante do galo pintado 
pelo artista espanhol Joan Miró, que virou símbolo máximo da fraternidade artística e obra principal da primeira etapa do Museu. Sobre o gesto de Miró, o presidente destacou:

Ele quis, não entregar um quadro, dos muitos ou dos poucos que têm em sua casa, ou em seu ateliê de trabalho, ele quis criar algo para o Chile. Foi mais generoso ainda. Ele pôs sua inteligência, suas pinceladas, sua mente para materializar este galo, que como disse o companheiro Pedrosa: "canta uma nova alvorada”, que é uma vida distinta, em um país dependente que rompe as amarras para derrotar o subdesenvolvimento e, com isso, a ignorância, a miséria, a incultura e as enfermidade (ALLENDE, 1972, pp. 1-2).

Em carta aos familiares, Pedrosa ressaltou a potência do galo de Miró, principal "símbolo para a retórica museográfica”, e comemorou os resultados positivos: "A ideia foi vitoriosa, e tudo foi feito no peito e na raça" (FIGUEIREDO, 1982, pp. 19-20). Certamente, a obra do artista espanhol congregou com êxito os objetivos iniciais da entidade, assegurando a importância do gesto solidário ao povo chileno, além de estamparacapa doúnicocatálogo do Museu publicado na época. O discurso proferido por Allende ressaltou a realidade dependente do país andino e a centralidade da cultura como forma de superar a condição subdesenvolvida 
da nação, em consonância com o escopo conceitual da entidade divulgado nos textos de apresentação do catálogo. Sempre que tinha oportunidade, o presidente salientava o mérito dos artistas em divulgar que "não apenas a independência econômica era importante, mas também a independência cultural" (ALLENDE, 1971, não paginado).

Os jornais transmitiram entusiasmados: "Inaugurou a mostra que conta com 600 obras. Estas foram doadas por pintores e escultores de todo o mundo" (LA NACIÓN, 1972, não paginado). $\mathrm{Na}$ realidade, foi exposta menos da metade das obras recebidas, por conta da limitação dos espaços do MAC. Apesar desse entrave, o nível da inauguração foi acima da média em comparação com as "boas exposições internacionais" (PEDROSA, 1972h, não paginado). Era um fato inédito agregar tantos nomes consagrados em uma única mostra, além de que se expunha pela primeira vez no país artistas como Miró, Vasarely, Jorge Oteiza, Equipo Cronica, entre outros. Sobre a organização da mostra, Pedrosa resumiu:

As obras aqui expostas não estão distribuídas arbitrariamente: buscou-se uma lógica interna que as unisse, e seus espaços correspondem, na medida do possível, a essa lógica. Todas as ideias ou estilos da arte contemporânea 


\section{Museo de la Solidaridad:}

LOS ARTISTAS DEL MUNDO

JUNTO AL PUEBLO DE CHILE

El Presidente de la República. Salvador Allende, inauguró la muestra que cuenta con 600 obras. Estas fueron donadas por pintores y escultores de todo el mundo.

La exposición tiene un valor de un millón de dólares.

E) Presidente de la Repubir. ca. Salvader Allenise, inauguro aver in ol Museo din Arte crate to Contemporanco de la Ouina Norma usa exposicion ge 600 cuadres que has ado donados ai preblo channo por aulskas of todo al mundo. Esta donacion es como sehal de simpatia po las felormas aue nn el campo social $Y$ oconbmico nata effectuan do oi Gobiemo de la Unidac Popular tos cuadros y obra escultoricas Que anoche comenraron a nxhobirse serd Is base del futurb Museo de 18 Solitavidad cue se attoblecer lungo en el edificio UNCTAD

La formacion de este Musec tesne una corta historia. En ene ro de este aho se forind e Com to Internacional de Solidaridad Artistica con Chile qué haro lie gev al Primer Mandalano chite. gav al Primer Mandalano chiteno su apoyo pot tos cambios revolucionarios impulsados A principios de afio al Comite hi. 20 une deciaración y on purte de ella manifiesia que confiamos que el gesto de exros artusta: no en el gexto walado de alow nus, tino mas bien comerpond: - un rasgo comin a ia calec bi

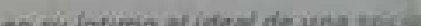

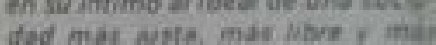

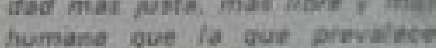
humane que la gue prevacese dat munde

Seguin les artistas incorpors dos al Comits nillos no puedh mirar con indifmencia our in th pintures. esculfurar y crear, pes seen monupolecetes para el poee entetre de coincevones tos privilegindos gue las purden cos porilepiados pue fas purdan

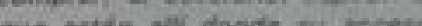
Que eutan all donde wu atrefe

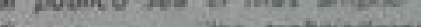
Agregan quin ios trabaypores de is cuitura de can todos the parses virivenst hacia of Chile de hoy Jeno de experansos to via chilene def secialome ex fo die enviver a la marorio de etlos a ofrecer de Chale des mejorz: Intos de su poder creative. it he hacen's sin ninguna obculen ete partidisme politice e sectave Sit hay politice en wo acceln at.

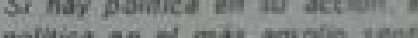

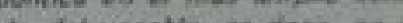
do del vacablo. es deci an an

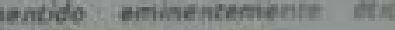
humanata y tbertario

CARTADEALHNDE Ei Jufe de fistato crando ins
FIGURA 4.

Museo de la Solidaridad: Los artistas del mundo junto al Pueblo de Chile.

El Clarín, 18 de maio de 1972.

Fonte: Arquivo Museu de Arte

Contemporânea da Faculdade de Artes,

Universidade do Chile (FAIMAC). 
do mundo estão aqui representadas. E vocês verão desde a linha lírica e criativa de Miró às obras que não exigem tanta contemplação, mas sim um chamado à ação revolucionária. O que une indissoluvelmente estas doações é precisamente este sentimento de fraternidade, para que jamais se dispersem em direções e destinos diferentes. (PEDROSA, 1972f, não paginado)

O desafio de expor uma coleção tão heterogênea, que desde o início correspondeu ao princípio de que "nenhuma tendência, escola, estilo ou ismo deve ser excluído" (Idem, 1972a, não paginado), foi evidenciado na fala inaugural de Pedrosa. Como mencionado, uma de suas táticas partiu de uma lógica interna de organização museográfica para dar conta do caráter diverso das obras. Segundo Silvia Cáceres, “a reflexão museológica de Mário Pedrosa compõe um todo orgânico onde tudo deve auxiliar para que esse espaço sirva às funções educadoras e reeducadoras da arte, da arquitetura e da forma" (CÁCERES, 2010, p. 111).

Nesse sentido, é fundamental ressaltar o caráter educativo do Museu da Solidariedade e vinculá-lo à concepção pedagógica da arte construída por Pedrosa em seu percurso como crítico e gestor. No caso chileno, tratava-se, primeiramente, de conservar as obras angariadas como um todo inseparável, formando um museu único, cujo acervo estaria em permanente exposição pública. Em segundo lugar, de 
assegurar que a solidariedade concretizada pela via das doações fosse reverenciada mediante a aproximação entre as "manifestações mais altas da plástica contemporânea" e as "grandes massas populares, inaugurando assim um tipo de relação inédita entre criadores da obra e o povo" (BORRADOR de un decreto para el Museo de la solidaridad, nd., não paginado). Por fim, tratava-se de garantir esse compromisso com os artistas doadores por meio das finalidades educativas e culturais do Museu, tendo como horizonte a sua "plena acessibilidade democrática, conforme o desejo dos doadores" (Ibidem). Essa resposta deveria estar de acordo com as necessidades da nova sociedade em construção, levando em consideração, sobretudo, a viabilidade da integração da arte com a esfera da vida, "expressão mais alta da via chilena ao socialismo" (Ibidem). A correspondência entre as revoluções política e estética, fundadas no princípio da liberdade como forma social e artística plenas, tornou-se um plano possível por intermédio da educação dos sentidos. A Dore Ashton, Pedrosa confidenciou: "coloco muitas esperanças nisso, pois acho que vou abrir um novo campo de experiências úteis entre os artistas criativos de todo o mundo e os mineiros chilenos" (PEDROSA, 1973b, Puro Chile, Santiago, 31 de maio de 1972. Fonte: Arquivo Museu de Arte Contemporânea da Faculdade de Artes, Universidade do Chile (FAIMAC). não paginado).

Os meios de comunicação, em compasso com as premissas basais doMuseu, ressaltaramo seu caráter populare acessívela toda 


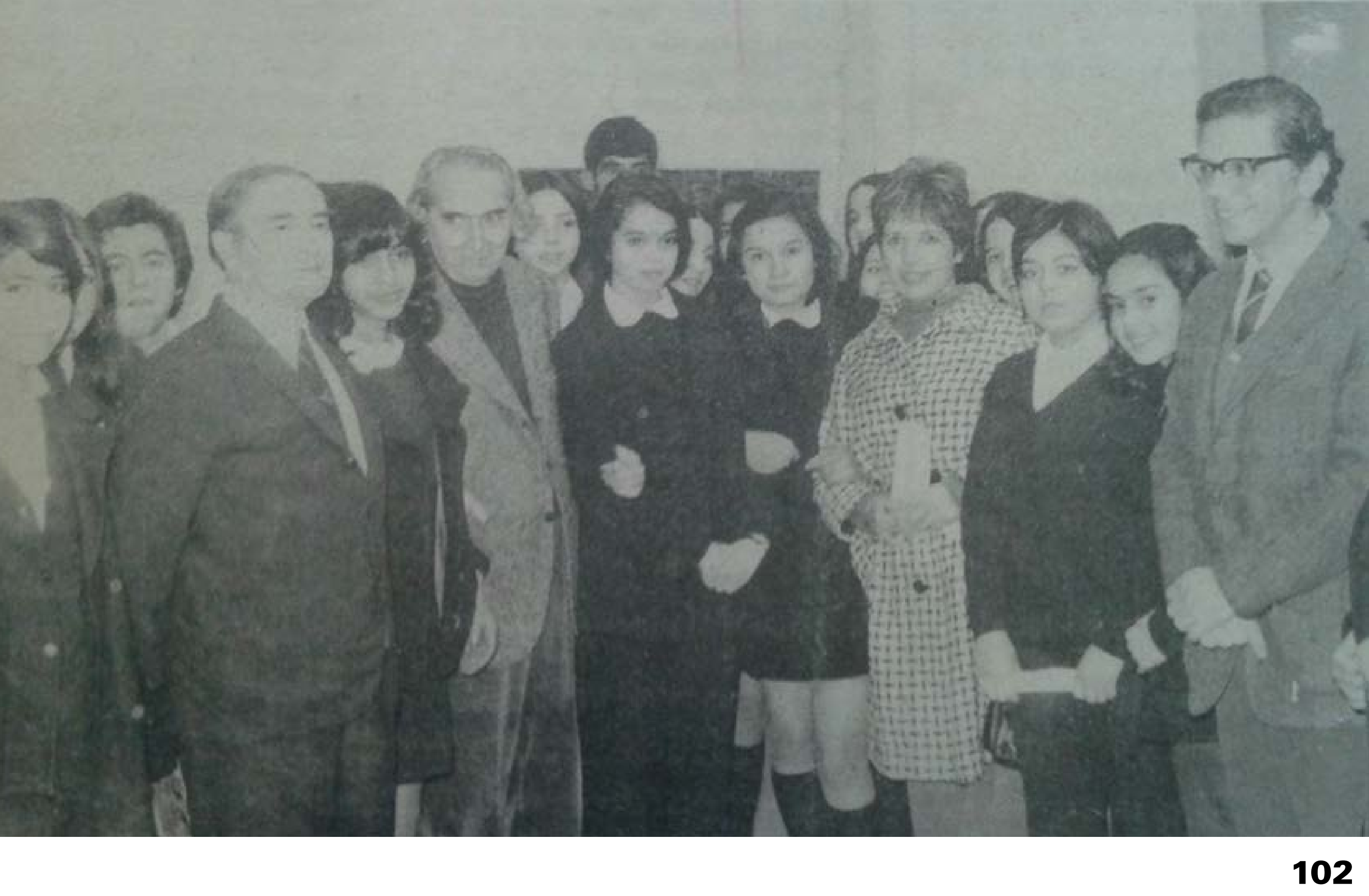


a população, inclusive à classe trabalhadora, que, historicamente, foi desvinculada dos espaços tradicionais de cultura e das artes plásticas. Em apenas um dia, cinco mil estudantes visitaram o Museu da Solidariedade. Uma matéria anunciava: "no interior do Museu, os estudantes acompanhados dos pintores nacionais recorreram às diversas dependências, apreciando as diferentes obras de arte contemporânea, doadas ao nosso país pelos melhores pintores de nossa época” (PURO CHILE, 1972, não paginado).

Para dar continuidade à ampliação do acervo do Museu, as redes decríticos ligados aoCISAC deveriamigualmente se expandir paraativaroscontatoseamplificarainiciativachilena.Porindicação de De Wilde e Jean Leymarie, o crítico londrino Roland Penrose e o suíço Harald Szeemann entraram para o Comitê Internacional do Museu (PEDROSA, 1972h, não paginado). A presença deste último no Comitê despertou o interesse de centenas de artistas que haviam participado da V Documenta de Kassel, organizada pelo suíço, em 1972, na Alemanha. Alguns anos antes, Szeemann curou a emblemática exposição "When Attitudes Become Form", cujo escopo conceitual ancorou-se no problema da forma artística tradicional ao expor um conjunto significativo de obras atravessadas pelo sentido da anti-forma. O evento reuniu artistas oriundos de movimentos de vanguarda da arte contemporânea 
da época, como arte conceitual, minimalismo, arte povera, entre outros, com proposições artísticas que colocavam em xeque o conceito de unicidade e permanência.

Paralelamente à V Documenta, Szeemann acionou mais de quatrocentos artistas que integraram a mostra alemã, reverberando os ecos do Museu da Solidariedade a um circuito global de artistas experimentais. Dessa rede, diversos artistas do núcleo de Szeemann entraram em contato com Pedrosa ao longo do ano de 1973, manifestando empatia à entidade e ao povo chileno e demonstrando interesse em doarobras ${ }^{12}$. O crítico admitiua Szeemann que, naquele momento inicial, o perfil da instituição era caracterizado por um acervo de obras mais convencionais, no entanto, havia interesse da entidade em modificar esse aspecto: "Então vamos precisar do seu conselho e da sua opinião, nossa ideia é fazer um museu dinâmico, experimental e não apenas tradicional, incluindo oficinas para artistas que desejam trabalhar no local” (PEDROSA, 1972k, não paginado). O curador suíço ficou conhecido por respaldar, no cenário internacional de exposições, um modelo de mostras que privilegiava o espaço do museu em favor da realização das obras, e não somente de sua exposição (LOUZADA, 2013, p. 22).

É essencial pontuar, contudo, que essa operação crítica e criativa em relação ao ambiente museal não era um fator inédito, 
tampouco exclusivo do circuito hegemônico que Szeemann representou. Ao longo das décadas de 1960 e 1970, historiadores e críticos brasileiros revolucionaram o conceito usual de museu, a exemplo de Walter Zanini, diretor do Museu de ArteContemporânea da Universidade de São Paulo (MAC-USP) entre 1963 e 1978. Nesse período, Zanini estabeleceu "uma plataforma de criação multidisciplinar e multimídia" ao tomar "um partido crítico e museológico que daria ênfase às práticas conceituais, incentivando o uso das novas tecnologias, em especial o vídeo" (FREIRE, 2013, p. 28).

Pedrosa também se aproximou de artistas experimentais cujas proposições abrangiam a dimensão participativa e coletiva, articulando uma leitura crítica não apenas das obras, mas, igualmente, da maneira como os espaços museológicos dialogavam com esses formatos não convencionais. Em "Arte Experimental e Museus", escrito em196o, ocríticoassegurava que "somenteàfrente de um museu de arte, dita moderna, é que se pode compreender a natureza intrínseca dessa mesma arte, e, de outro lado, o papel que cabe ao museu na avaliação dela" (PEDROSA, 1995, p. 295). No mesmo texto, o crítico considerava indispensável superar a função tradicional dos museus, cedendo o seu lugar a uma formulação mais arejada, que levasse em consideração o sentido de invenção 
ou, nas palavras do autor, "uma casa de experiências" para a arte experimental (PEDROSA, 1995, p. 295).

No âmbito latino-americano, o Centro de Arte y Educación

- CAYC, dirigido por Jorge Glusberg, procurou reproduzir um modelo internacional de espaços culturais e exposições de vanguarda, atualizando os projetos mais contemporâneos do circuito hegemônico no contexto local. $O$ crítico de arte argentino concebeu um modelo expográfico baseado no uso de heliografias, possibilitando a ampla circulação de suas exposições e a adesão de centenas de artistas latino-americanos e nomes proeminentes do cenário artístico estrangeiro. Em 1973, Glusberg enviou uma versão desse tipo de exibição, a “Art Systems II”, para o Museu Nacional de Belas Artes do Chile, dirigido pelo pintor Nemesio Antúnez ${ }^{13}$. Muitos artistas que integraram a V Documenta fizeram parte da mostra organizada por Glusberg, e a ressonância dessa rede compartilhada e amparada por produções experimentais de caráter conceitual ecoou no Museu da Solidariedade. Na ocasião, Mário Pedrosa escreveu ao argentino sobre o assunto ${ }^{14}$ :

Acabo de receber carta de Agnes Denes, atendendo ao apelo de Harald Szeemann, para contribuir com uma doação ao nosso Museu da Solidariedade [...]. Ela me informou que participou de uma exposição 
organizada pelo CAYC e que esta mostra ocorreu no Museu de Belas Artes [...]. Harald Szeemann convocou todos os artistas que participaram da Documenta V. São artistas de todos os gêneros e expressão, dos, digamos, já clássicos aos mais jovens e experimentais, como você pode testemunhar pelo o que está acontecendo no CAYC. (PEDROSA, 1973a, não paginado) ${ }^{15}$

Além de organizar e aumentar as redes de artistas, Pedrosa tinha a missão de formalizar, em termos jurídicos e legais, um espaço oficial para o Museu da Solidariedade. Até aquele momento, as obras ficavam armazenadas no MAC e no IAL. O objetivo era que o Museu ganhasse uma sede no Parque O’Higgins, local de fácil acesso para a população, garantindo o perfil popular da entidade. Em outra carta, dessa vez enviada a Mathias Goeritz, arquiteto e artista alemão radicado no México, Pedrosa ressaltou a potência que o Parque tinha para a iniciativa, ao assegurar a dimensão aberta e democrática como instâncias essenciais do Museu:

[...] eu já sabia que você não fazia mais coisas para 'serem colocadas em um museu', mas o nosso museu não é um museu fechado, do tipo mausoléu. O nosso estará localizado em um grande parque com grandes árvores [...]. O exterior do nosso museu será - assim é a minha ideia - tão importante como o interior. (Idem, 1972j, não paginado) 
$-2-$

Jorse Gluabers

2171410 Gonsalen 4020

Buence Ayres

Zat1mado Gluaborgt

Roabo de reatbir onrte de Acrue Dones, atendiendo al spolo Ie Hirild 3zegann, parn oantribuir oon uni donselon al muestro

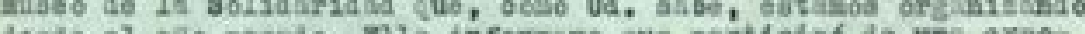

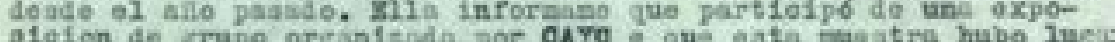

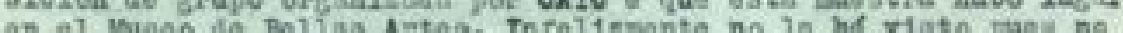

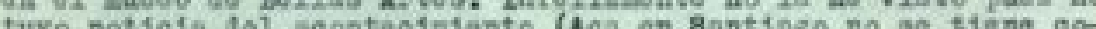

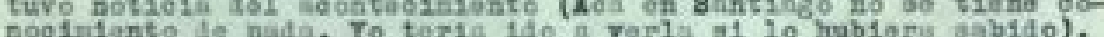

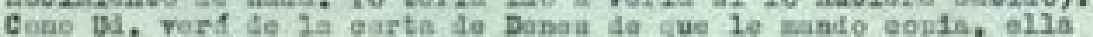

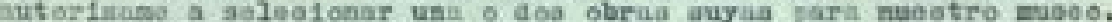
Zoo 10 hure oan grin out1afiogelen. Que debo hieer pars eao?

Otro dil tanbion reo1b1 oarta de otro aniso, Janoo Jrban,

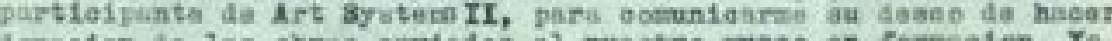

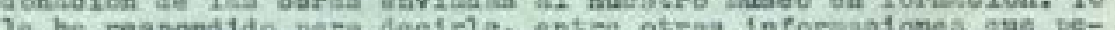

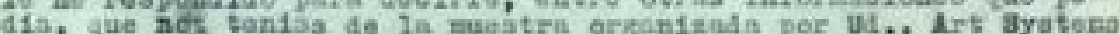

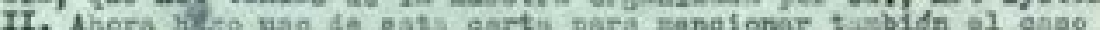

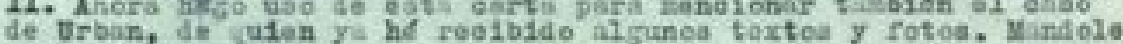
gopia do us girts.

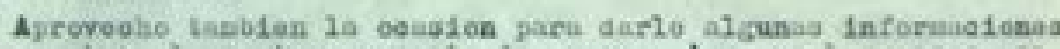

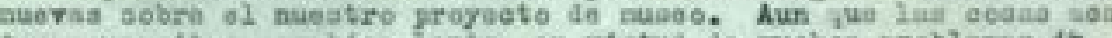

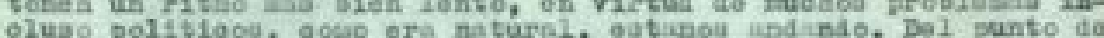

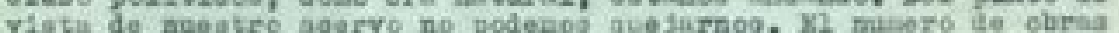

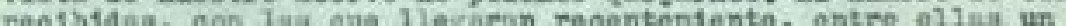

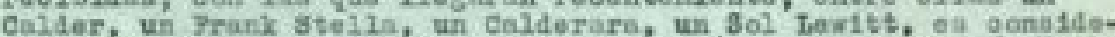
rabie, y gon lia raoibidas anteriorpente (entre elina Mirs, Vase-

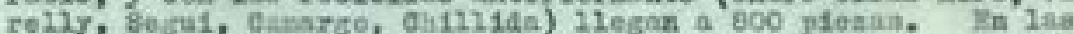

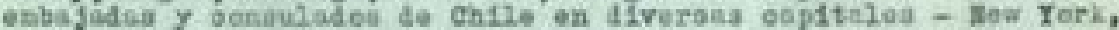

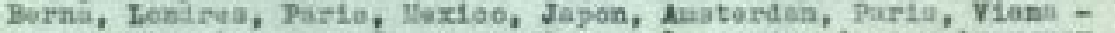

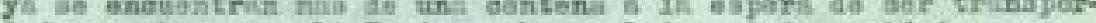

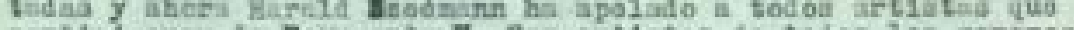

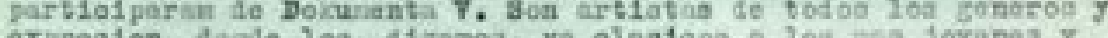

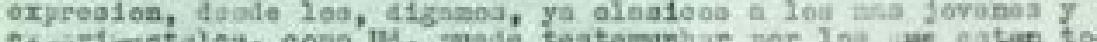

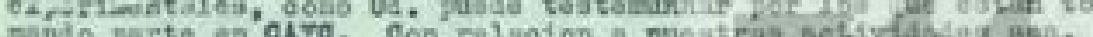

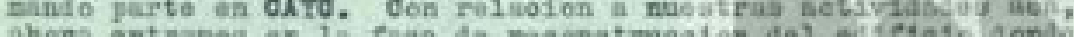

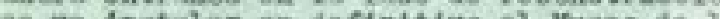

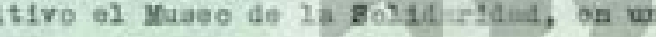

meisereican

SALYAOOR ALLFNDE

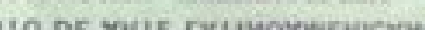

belo parvue en ronolelsoidn urbaniation on un quarteron popular do is ofvifad. Zaporinos teriding lisa obran parn is proxis pri-

in 1 in eaporinzas to ofrlo on breve,

Cordinisonte,

Yarto Pedross

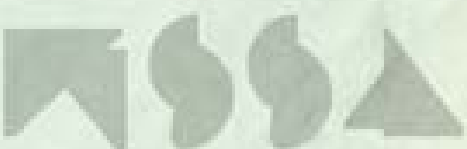

cusedo ot 0

SALVDOOR ALIENDE

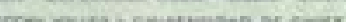

ixesunto of vue rvimovicticvio 
O testemunho de Pedrosa a Goeritz sobre a entidade chilena é revelador por dois aspectos: primeiro, por esclarecer os princípios de seu pensamento museológico, que compreendiam a convicção das esferas pública e democrática para a eficácia social do projeto. O grau de relevância que o crítico conferia aos espaços externos seguia em consonância com a sua concepção de arte defendida desde a década de 1950, relacionada, sobretudo, à ideia de síntese das artes representada pela construção da nova capital. Nessa perspectiva, a noção de síntese não abrangia apenas a interlocução efetiva entre as distintas linguagens artísticas, mas, especialmente, a integração das artes como potencial mobilizador social que essa fusão artística presumia.

A segunda exposição do Museu da Solidariedade foi inaugurada no dia 19 de abril de 1973, em meio a um ambiente político cada vez mais fragilizado. A abertura serviu para anunciar as doações que continuaram a chegar de todas as partes, reiterando o apoio da classe artística internacional à experiência socialista chilena. No MAC, foram expostas 105

Carta a Jorge Glusberg. 20 fev. 1973. Fonte: Arquivo Museu da Solidariedade Salvador Allende. obras, entre pinturas e esculturas. No edifício da UNCTAD, 54 obras em papel, como desenho, gravura e têmperas, estavam à disposição do público. Apesar do número modesto de obras que integraram a segunda mostra, àquela altura, o acervo do Museu 
abrigava aproximadamente 900 obras, além de 100 trabalhos que se encontravam em diversas embaixadas chilenas aguardando o envio definitivo à entidade $\mathrm{e}^{16}$.

\section{EPÍLOGO}

A experiência chilena despertou o interesse de diferentes círculos da esquerda de todo o mundo, que vislumbraram a viabilidade da implantação do socialismo por meio da via democrática e pacífica. A revolução andina representou "um processo político inédito na história e, por essa razão, acabaria ganhando repercussão mundial, no momento de sua vigência e mesmo após o seu desfecho" (AGGIO, 2008, p. 78). Embora o epílogo tenha sido trágico, essa experiência extraordinária concretizou um projeto utópico que se ancorou, sobretudo, no sentimento de solidariedade e empatia para além das fronteiras nacionais, mobilizando o gesto fraterno de comprometimento com a construção de outros mundos possíveis. As utopias que circundaram o Museu da Solidariedade e seus inúmeros projetos, mesmo os que não saíram do papel, simbolizaram o sonho pela 
emancipação política e cultural, o bem-estar social e a revolução dos sentidos por meio da arte e da liberdade.

O golpe de Augusto Pinochet não só sepultou a promessa de um governo socialista e democrático na região como também produziu uma diáspora de exilados que tiveram de sair às pressas do Chile. A partilha de um projeto coletivo e democrático de integração latino-americana foi substituída por outra modalidade de união continental, porém de contornos sinistros: a Operação Condor. Como o fascismo não partilha a mesma língua da solidariedade, o Museu foi soterrado pela ditadura, que enxergou na iniciativa os resquícios da revolução política de Allende; logo, seus ecos deveriam ser silenciados como parte da política oficial. Contudo, conforme aponta Claudia Zaldívar, o regime se viu mergulhado em uma contradição: como destruir uma coleção de enorme valor material e simbólico? Nessa condição, a entidade foi escondida, ocultada da opinião pública e suas portas fechadas, “como se nunca tivesse existido" (ZALDÍVAR, 1991, p. 57).

Não obstante, as raízes baseadas no afeto, na empatia e no ideal de coletividade, alicerces fundamentais do Museu da Solidariedade, foram mais resistentes que a desumanidade imposta pelo regime ditatorial. Na condição de exilados, os múltiplos agentes envolvidos na gestão do Museu mobilizaram 
novos simpatizantes, que, unidos em diversos países, deram continuidade à iniciativa. No estrangeiro, a entidade recebeu um novo nome: Museu Internacional da Resistência Salvador Allende $^{17}$. Mário Pedrosa conseguiu fugir para o México e, logo depois, exilou-se em Paris, seu último desterro antes de voltar ao Brasil, em 1977. 
1. Ver: JUIZ decreta a prisão de implicados em publicações contra o país no exterior. Jornal do Brasil, Rio de Janeiro, 30 jul. 1970. Arquivo CEDEM - Centro de Documentação e Memória da UNESP. Fundo Mário Pedrosa.

2. Traduções de obras e documentos citados apenas no original são de minha autoria. [N.A]

3. Termo criado por Alfred Sauvy em 1952.

4. A ideia de renomear o museu como Museu de Solidariedade partiu do presidente Salvador Allende. Cf. PEDROSA (n.d., p. 1).

5. Em um documento de novembro de 1971, os nomes de Roberto Matta, José Balmes, Miguel Rojas Mix e Pablo Neruda apareciam como integrantes do CISAC. Entretanto, o próprio Pedrosa ressaltou "a personalidade estrangeira" do Museu, e, logo depois, foi decidido que nenhum chileno faria parte do Comitê. A ideia era que a iniciativa conservasse o princípio internacionalista, incluindo apenas estrangeiros "movidos pela simpatia ao povo chileno e seu Governo popular" (PEDROSA, n.d., p. 1). Em carta a Dore Ashton, de janeiro de 1972, Pedrosa também ressalta o perfil internacionalista do CISAC, formado por “não chilenos". Cf. PEDROSA (1972b, não paginado).

6. Edward de Wilde liderou o boicote da delegação holandesa à Bienal Internacional de São Paulo em 1969.

7. Mário Pedrosa tentou ampliar a presença latino-americana do CISAC por meio de um convite a Niomar Moniz Sodré, em março de 1972, para quem escreveu: "A pessoa que desde o começo pensei em ser a mais indicada do Brasil foi você naturalmente". Entretanto, a fundadora do MAM-RJ não pôde aceitar o convite, por prováveis retaliações do regime militar. Em 1969, ela foi presa e teve os direitos políticos cassados pela ditadura. No ano seguinte, foi absolvida. Cf. PEDROSA (1972c). 
8. Documento originalmente publicado em janeiro de 1972.

9. Essas menções aparecem em uma carta de Pedrosa a Dore Ashton de 15 de junho 1972 e em PEDROSA (n.d., p. 3).

10. Em carta de Pedrosa a Ashton, o brasileiro estendeu essa incerteza ao crítico inglês Guy Brett. Ele escreveu: "Sou amigo pessoal do Guy Brett, do The Times, de quem gosto e a escrita eu admiro. Mas acho que ele é muito alheio à política para entender a importância de nosso movimento" (PEDROSA, 1972b, não paginado). Contudo, em correspondências posteriores, o autor confirmou o auxílio de Brett no envio de artistas britânicos. A Oiticica, contou: "Guy Brett em Londres reuniu uma turma disposta a mandar coisas ou 'ideias' para nós aqui. Entre eles estará Medalla", em referência ao artista filipino, radicado na época em Londres. (PEDROSA, 1972g, não paginado).

11. A bandeira foi instalada quarenta anos depois, na mesma escala planejada por Antonio Dias no projeto original, na ocasião da mostra "40 Años del Museo de la Solidaridad. Fraternidad, Arte y Política", em 2012.

12. No arquivo do Museu da Solidariedade foram encontradas cartas enviadas por 26 artistas da rede de Harald Szeemann, como Ian Murray, Samuel Buri, Yona Friedman, Getulio Alviani, Agnes Denes, logeborg Lüsher, Dan Graham, Ian Murray, entre outros.

13. Contudo, essa mostra de heliografias não foi apresentada, devido ao golpe militar.

14. Cabe mencionar que Pedrosa e Glusberg encontravam-se em direções opostas no espectro político. 0 crítico brasileiro liderou o boicote à $X$ Bienal, em resposta à censura e à repressão do regime militar brasileiro, em 1969. No certame seguinte, em 1971, o argentino foi convidado para organizar a edição da XI Bienal, todavia acabou desistindo após uma ofensiva de manifestos encabeçados por artistas, como Gordon Matta-Clark. Além disso, a figura de Jorge Glusberg é bastante controversa na Argentina, pela proximidade que manteve com o regime militar (1976 a 1983). Sobre o assunto, cf. PALADINO (2015).

15. Vale pontuar que "Art Systems II" foi enviada ao Museu, mas acabou não sendo exposta devido ao golpe militar. Após a queda de Allende, o CAYC organizou a mostra "Homenaje a Salvador Allende", “líder da América lamentavelmente desaparecido", em outubro de 1973. 
16. As quase mil obras que formavam o patrimônio da entidade foram divulgadas na matéria Hoy se Inaugura segunda exposión del Museo de la Solidaridad, escrita por Virginia Vidal. Cf. VIDAL (1973)In: Jornal El Siglo, Santiago, 19 abr. 1973. Arquivo Museu da Solidariedade.

17. Embora o Museu Internacional da Resistência Salvador Allende não seja objeto de análise deste trabalho, vale ressaltar que a entidade funcionou no exílio entre 1975 e 1990 e foi um importante veículo de campanha internacional de denúncia do regime autoritário que se instalou no Chile. Sobre a fase do Museu no exílio, ver YASKY (2016). 


\section{REFERÊNCIAS BIBLIOGRÁFICAS}

AGGI0, Alberto. 0 Chile de Allende: entre a derrota e o fracasso. In FICO, Carlos et al. Ditadura e Democracia na América Latina: Balanço Histórico e Democracia na América Latina. Rio de Janeiro: Editora FGV, 2008.

ALLENDE, Salvador. Palavras do Presidente da República Salvador Allende Gossens na inauguração do Museu da Solidariedade. Santiago, 17 de maio de 1972. In COMITÉ Internacional de Solidaridad Artistica con Chile. Museo de la Solidaridad: Donación de los artistas del mundo al gobierno de Chile. Instituto de Arte Latinoamericano, Universidad de Chile, 1972, pp. 1-2.

ARANTES, Otília. Mário Pedrosa e a Tradição Crítica. In: MARQUES NETO, José Castilho. Mário Pedrosa e o Brasil. São Paulo: Editora Perseu Abramo, 2001.

ASHTON, Dore. Tiempos de Solidaridad: Conversasión con Dore Ashton. In COMITÉ Internacional de Solidaridad Artística con Chile. Museo de la Solidaridad por Chile: Fraternidad, Arte y Política, 1971-1973. Santiago: Museo de la Solidaridad Salvador Allende, 2013, pp. 56-62.

BERRÍOS, María. Por el futuro artístico del mundo: Mário Pedrosa y el Museo de la Solidaridad. In PÉREZ- BARREIRO, Gabriel; SOMMER, Michelle (orgs.). Mário Pedrosa: De la naturaleza afectiva de la forma. Madrid: Museo Nacional Centro de Arte Reina Sofía, 2017. 
CÁCERES, Gonzalo. Santiago, a capital da esquerda. In GORELIK, Adrian; PEIXOTO, Fernanda Arêas (orgs.). Cidades Sul-americanas como arenas culturais. São Paulo: Edições Sesc, 2019.

CÁCERES, Silvia. Fulguração Moderna: A Educação pela Arte no Museo de la Solidaridad, Chile, 1971-1973. 195f. Dissertação (Mestrado em Educação)

- Programa de Pós-Graduação em Educação, Pontifícia Universidade Católica do Rio de Janeiro (PUC-RIO), Rio de Janeiro, 2010.

FERRERO, Mariano. Salvador Allende: su mundo, su época - La Política Internacional del Siglo XX y sus encrucijadas en la Guerra Fría. In: AMAR, Mauricio; VÁSQUEZ, David; RIVERA, Felipe (orgs.). Salvador Allende: Vida Política y Parlamentaria - 1908-1973. Santiago: Ediciones Biblioteca del Congreso Nacional de Chile, 2008.

FIGUEIREDO, Carlos Eduardo Sena (org.). Mário Pedrosa, Retratos do Exílio. Rio de Janeiro: Edições Antares, 1982.

FREIRE, Cristina (org.). Walter Zanini: escrituras críticas. São Paulo: Annablume; MAC USP, 2013.

GILMAN, Claudia. Entre la pluma y el fusil: debates y dilemas del escritor revolucionario en América Latina. Buenos Aires: Siglo XXI Editores, 2003. 
KAREPOVS, Dainis. Pas de Politique Mariô!: Mário Pedrosa e a Política. São Paulo: Fundação Perseu Abramo, 2017.

KORNBLUH, Peter. Pinochet: Los Archivos Secretos. Barcelona: Editora CRÍTICA, 2004.

LOUZADA, Heloisa. Contrastes na cena artística paulistana: MAC USP e MAM SP nos anos 1970. 163f. Dissertação (Mestrado Estética e História da Arte) - Programa de Pós-Graduação Interunidades em Estética e História da Arte, Universidade de São Paulo, São Paulo, 2013.

MACCHIAVELLO, Carla. Una Bandera es Una Trama. In COMITÉ Internacional de Solidaridad Artística con Chile. Museo de la Solidaridad por Chile: Fraternidad, Arte y Política, 1971-1973. Santiago: Museo de la Solidaridad Salvador Allende, 2013, pp. 28-43.

PALADINO, Luiza Mader. Conceitualismos em Trânsito: intercâmbios artísticos entre Brasil e Argentina na Década de 1970 - MAC USP e CAY. 213f. Dissertação (Mestrado em Estética e História da Arte) - Programa de Pós-Graduação Interunidades em Estética e História da Arte. Universidade de São Paulo, São Paulo, 2015.

PEDROSA, Mário. Política das Artes: Mário Pedrosa. Textos escolhidos I. Organização e prefácio de Otília Arantes. São Paulo: Edusp, 1995. 
PEDROSA, Mário. Acadêmicos e Modernos: Mário Pedrosa. Textos escolhidos III. Organização e prefácio de Otília Arantes. São Paulo: Edusp, 2004.

PEDROSA, Mário. Mundo, Homem, Arte em Crise: Mário Pedrosa. Organização de Aracy Amaral. São Paulo: Ed. Perspectiva, 2007.

PEDROSA, Mário; TRELLES, Danilo. Declaración. In COMITÉ Internacional de Solidaridad Artistica con Chile. Museo de la Solidaridad: Donación de los artistas del mundo al gobierno de Chile. Instituto de Arte Latinoamericano, Universidad de Chile, 1972.

SALZSTEIN, Sônia. Mário Pedrosa: Crítico de Arte. In MARQUES NETO, José Castilho. Mário Pedrosa e o Brasil. São Paulo: Editora Perseu Abramo, 2001.

WASSERMAN, Claudia. Transição ao Socialismo e Transição Democrática: exilados brasileiros no Chile. História Unisinos, 16(1), jan.-abr. 2012.

YASKY, Caroll; ZALDÍVAR, Claudia (org.). Museo Internacional de la Resistencia Salvador Allende. MIRSA. 1975 - 1990. Santiago: Museo de la Solidaridad Salvador Allende, 2016.

ZALDÍVAR, Claudia. Museo de la Solidaridad. Memoria para optar al grado de Licenciado en Teoría e Historia del Arte. Santiago de Chile. 1991. Fondos y Colecciones Especiales. Cod: i0042. Archivo MSSA. 
ZALDÍVAR, Claudia. Un modelo Cultural Experimental para el Mundo. In COMITÉ Internacional de Solidaridad Artística con Chile. Museo de la Solidaridad por Chile: Fraternidad, Arte y Política, 1971-1973. Santiago: Museo de la Solidaridad Salvador Allende, 2013, pp. 9-13.

ARQUIVOS E JORNAIS

ALLENDE, Salvador. Cultura sobre rodas. La Nación, Santiago, 17 fev. 1971, não paginado.

ALLENDE, Salvador. Carta de Salvador Allende a José María Moreno Galván. Santiago, 11 ago. 1971. Arquivo Museu Nacional Centro de Arte Reina Sofía.

ASHTON, Dore. Carta de Dore Ashton a Mário Pedrosa. 22 nov. 1971. Arquivo Museu da Solidariedade Salvador Allende.

ASHTON, Dore. Carta de Dore Ashton a Mário Pedrosa. 18 jan. 1972. Arquivo Museu da Solidariedade Salvador Allende.

BORRADOR de un decreto para el Museo de la solidaridad. Sem autor, n.d. Arquivo CEDEM - Centro de Documentação e Memória da UNESP. Fundo Mário Pedrosa. 
DIAS, Antonio. Carta de Antonio Dias a Mário Pedrosa. 17 mar. 1972. Arquivo Museu da Solidariedade Salvador Allende.

FOLHA DE S. PAULO. Mário Pedrosa morre aos 81 anos. Folha de São Paulo, São Paulo, 6 nov. 1981. Arquivo CEDEM - Centro de Documentação e Memória da UNESP. Fundo Mário Pedrosa.

GULLAR, Ferreira. 0 crítico da crise. Estadão, São Paulo, 6 nov. 1981. Arquivo CEDEM - Centro de Documentação e Memória da UNESP. Fundo Mário Pedrosa.

LA NACION. Museo de la Solidaridad: Los Artistas del Mundo junto al Pueblo de Chile. La Nación. Santiago, 18 maio. 1972. Arquivo Museu da Solidariedade Salvador Allende.

PEDROSA, Mário. Vozes da Ásia, Vozes d’África: A conferência de Bandung. Correio da Manhã, 16 abr. 1955. Arquivo Biblioteca Nacional.

PEDROSA, Mário. Carta redigida em 5 ago. 1970, após ter a sua prisão decretada. Arquivo CEDEM - Centro de Documentação e Memória da UNESP. Fundo Mário Pedrosa.

PEDROSA, Mário. Carta de Mário Pedrosa a Dore Ashton, 2 jan, 1972a, não paginado. Arquivo Museu da Solidariedade Salvador Allende. 
PEDROSA, Mário. Carta de Mário Pedrosa a Dore Ashton, 9 jan, 1972b, não paginado. Arquivo Museu da Solidariedade Salvador Allende.

PEDROSA, Mário. Carta de Mário Pedrosa a Niomar Moniz Sodré, 1 mar, 1972c, não paginado. Arquivo Museu da Solidariedade Salvador Allende.

PEDROSA, Mário. Carta de Mário Pedrosa a Antonio Dias, 6 mar, 1972d, não paginado. Arquivo Museu da Solidariedade Salvador Allende.

PEDROSA, Mário. Carta de Mário Pedrosa a Aracy Amaral, 16 abr, 1972e, não paginado. Arquivo Museu da Solidariedade Salvador Allende.

PEDROSA, Mário. Oigamos el canto del Gallo de Miró. El Siglo, Santiago, 19 maio, 1972f, não paginado. Arquivo Museu da Solidariedade Salvador Allende.

PEDROSA, Mário. Carta de Mário Pedrosa a Hélio Oiticica, 9 jun, 1972g, não paginado. Arquivo Museu da Solidariedade Salvador Allende.

PEDROSA, Mário. Carta de Mário Pedrosa a José María Moreno Galván, 28 jun, 1972h, não paginado. Arquivo Museu da Solidariedade Salvador Allende.

PEDROSA, Mário. Carta de Mário Pedrosa a Mathias Goeritz, 29 set, 1972i, não paginado. Arquivo Museu da Solidariedade Salvador Allende. 
PEDROSA, Mário. Carta de Mário Pedrosa a Mathias Goeritz, 7 nov, 1972j, não paginado. Arquivo Museu da Solidariedade Salvador Allende.

PEDROSA, Mário. Carta de Mário Pedrosa a Harald Szeemann, 22 nov, 1972k, não paginado. Arquivo Museu da Solidariedade Salvador Allende.

PEDROSA, Mário. Carta de Mário Pedrosa a Jorge Glusberg, 20 fev, 1973a, não paginado. Arquivo Museu da Solidariedade Salvador Allende.

PEDROSA, Mário. Carta de Mário Pedrosa a Dore Ashton, 27 mar, 1973b, não paginado. Arquivo Museu da Solidariedade Salvador Allende.

PEDROSA, Mário. Carta de Mário Pedrosa a Dore Ashton, 27 abr, 1973c, não paginado. Arquivo Museu da Solidariedade Salvador Allende.

PEDROSA, Mário. Respuesta a un Cuestionario, por Mário Pedrosa. Sem data, p. 3. Arquivo Museu da Solidariedade Salvador Allende.

PURO CHILE, 5 mil estudiantes. Puro Chile, Santiago, 31 maio. 1972. Arquivo Museu de Arte Contemporânea da Faculdade de Artes, Universidade do Chile (FAIMAC).

VIDAL, Virginia. Hoy se Inaugura segunda exposión del Museo de la Solidaridad. El Siglo, Santiago, 19 abr. 1973. Arquivo Museu da Solidariedade. 


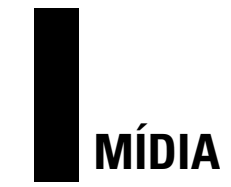

MUSEO DE LA SOLIDARIDAD. Entrevista a Dore Ashton, en el marco de los 40 años del MSSA, 11 abril 2016. Disponível em: https://vimeo.com/162437339. Acesso em: 10 maio 2019. 


\section{SOBRE A AUTORA}

Luiza Mader Paladino é Doutora pelo Programa de Pós-graduação Interunidades em Estética e História da Arte da Universidade de São Paulo, onde desenvolveu a tese “A Opção Museológica de Mário Pedrosa: Solidariedade e Imaginação Social em Museus da América Latina". Mestra pelo mesmo Programa, com dissertação sobre o intercâmbio artístico entre o CAYC e o MAC USP, dois polos essenciais de estímulo à arte conceitual na América Latina, na década de 1970. Integrante do GEACC - Grupo de Estudos em Arte Conceitual e Conceitualismos no Museu, coordenado pela Profa. Dra. Cristina Freire. Professora efetiva do Instituto Federal de Brasília. 